\title{
Role of the pulsed dye laser in the management of ulcerated capillary haemangiomas
}

\author{
M Lacour, S Syed, J Linward, J I Harper
}

\begin{abstract}
A complication of capillary haemangiomas is ulceration, which may arise after trauma and/or infection. Until recently, conservative management was the rule. However, the recent advent of the pulsed dye laser has revolutionised the treatment of vascular birthmarks and provided a new tool for the management of capillary haemangiomas. Thirteen cases of ulcerated capillary haemangiomas referred to our department were reviewed; five were treated conservatively and eight were treated with the laser. Those treated with the laser had all failed conservative management and healed completely within one to four weeks. Remarkably rapid alleviation of pain was achieved. For those haemangiomas around the mouth and perineum, laser treatment enabled early restoration of normal feeding, micturition, and defaecation.

It is therefore recommended that if ulcerated capillary haemangiomas do not improve after a short period of optimal conservative treatment, laser treatment should be considered.

(Arch Dis Child 1996; 74: 161-163)
\end{abstract}

Keywords: capillary haemangioma, pulsed dye laser.

Capillary haemangiomas are common birthmarks affecting around one in 20 infants. They appear at or soon after birth and follow a well defined course characterised by progressive enlargement until 3 to 6 months of age, a static phase, and then spontaneous resolution before 7 years of age. The majority of these remain uncomplicated and disappear completely. Hence, no treatment is usually recommended. Rarely, serious complications arise because of their location. Periocular lesions leading to eyelid closure may cause amblyopia. Airway obstruction may occur from deep infiltration by a large cavernous haemangioma in the neck or floor of the mouth. Large haemangiomas can also be complicated by a coagulopathy (Kasabach-Merritt syndrome) due to platelet entrapment. In these situations, the treatment of choice is oral steroids at an initial dose of $2-3 \mathrm{mg} / \mathrm{kg} /$ day. $^{1}$

Another problem that may arise is ulceration secondary to trauma and/or infection, especially in haemangiomas located on the nose, lips, genitalia, or axillae. Treatment until recently has been conservative for all such lesions with regular daily cleaning, dressings, and antibiotics. In some cases the lesions heal rapidly.

However, others may take a long time to heal, cause pain and distress to the child, and can result in scarring. In the past decade, a number of treatment alternatives, such as argon, neodymium:yttrium aluminium garnet (Nd:YAG) or carbon dioxide lasers, cryosurgery and surgical excision, have been put forward but failed to prove beneficial other than in isolated cases. $^{2}$

The recent availability of the $585 \mathrm{~nm}$ flashlamp pulsed dye laser has, however, revolutionised the treatment of vascular birthmarks. Due to its unique capacity of selectively damaging cutaneous blood vessels to a depth of $1.2 \mathrm{~mm}$, it is now the treatment of choice for port wine stains and telangiectases. ${ }^{34}$ When handled correctly, adverse effects are negligible. ${ }^{5}$

The pulsed dye laser has also been reported to effectively treat ulcerated haemangiomas. ${ }^{67}$ We have critically reviewed all children with ulcerated haemangiomas referred to our department over the past six months, some of whom were treated conservatively and others who have received laser treatment, in order to define a strategy of management.

\section{Patients and methods}

Thirteen children (three boys, 10 girls) were referred to our department with ulcerated haemangiomas. Age at presentation ranged from 1 to 12 months. Initial assessment included medical history and physical examination as well as swabs for bacteria and yeasts. Initial management was conservative in all cases with local cleaning, a topical antimicrobial preparation, and systemic antibiotics if required. Laser treatment was performed under general anaesthesia with a flash lamp pulsed dye laser (585 nm, SPTL-1b, Candela). Using a $7 \mathrm{~mm}$ probe, lesions were lasered with a mean of 100 pulses (range 28-352) at $7 \cdot 5$ to $8.5 \mathrm{Joules} / \mathrm{cm}^{2}$

Preoperatively, patients were given diclofenac sodium orally. Postoperative care consisted of ice packs to reduce swelling, mupirocin ointment until healing, and antibiotic prophylaxis for potentially infected areas such as the perineum. Healing was defined as complete re-epithelialisation of the ulcer. One patient, with systemic haemangiomatosis, was taking oral prednisone at the time of laser treatment.

\section{Results}

As seen in the table, five children were treated with conservative management alone and did not have any intervention with laser treatment. Ulcerated areas on planar surfaces (patients 2, 3) healed within six weeks whereas those
Correspondence to: Dr Harper.

Accepted 4 October 1995 
Clinical data, management, and outcome of 13 cases of ulcerated capillary haemangiomas

\begin{tabular}{|c|c|c|c|c|c|c|c|}
\hline \multirow{2}{*}{$\begin{array}{l}\text { Patient } \\
\text { No }\end{array}$} & \multirow{2}{*}{$\begin{array}{l}\text { Age at } \\
\text { presentation } \\
\text { (months) }\end{array}$} & \multirow{2}{*}{$\begin{array}{l}\text { Ulcerated area } \\
\text { (No, size, location) }\end{array}$} & \multirow[b]{2}{*}{ Associated features } & \multirow{2}{*}{$\begin{array}{l}\text { Time } \\
\text { ulcerated } \\
\text { before } \\
\text { treatment } \\
\text { (weeks) }\end{array}$} & \multicolumn{2}{|c|}{ Management } & \multirow[b]{2}{*}{ Outcome } \\
\hline & & & & & Laser & Medical & \\
\hline 1 & 4 & $1,8 \mathrm{~cm}^{2}$, dorsum of & Bleeding at multiple sites & 4 & No & IV and oral antibiotics & Healed after 10 weeks \\
\hline 2 & 6 & $1,2 \mathrm{~cm}^{2}$, neck & & 8 & No & Mupirocin & Healed after 3 weeks \\
\hline 3 & $4 \cdot 5$ & $\begin{array}{l}1,50 \mathrm{~cm}^{2} \text {, shoulder } \\
\text { and thorax }\end{array}$ & $\begin{array}{l}\text { Sepsis, anaemia, required } \\
\text { transfusion }\end{array}$ & 4 & No & IV and oral antibiotics & Healed after 6 weeks \\
\hline 4 & 2 & $1,1 \mathrm{~cm}^{2}$, lower lip & $\begin{array}{l}4 \text { Weeks premature; oral } \\
\text { candidiasis }\end{array}$ & 3 & No & $2 \%$ Miconazole gel & Healed after 4 weeks \\
\hline 5 & 2 & $1,2 \mathrm{~cm}^{2}$, upper lip & & 2 & No & $2 \%$ Miconazole gel & Healed after 3 weeks \\
\hline 6 & 6 & $1,4 \mathrm{~cm}^{2}$, neck & Ulcer in skinfold & 6 & No & $\begin{array}{l}\text { Mupirocin, oral } \\
\text { antibiotics }\end{array}$ & $\begin{array}{l}\text { Initially treated conservatively, slow healing } \\
\text { due to repetitive movements. Infection at } 9 \\
\text { weeks requiring IV antibiotics. Recurrence } \\
\text { at } 12 \text { weeks lasered with healing in } 4 \text { weeks }\end{array}$ \\
\hline \multirow[t]{2}{*}{7} & 1 & $\begin{array}{l}2,1 \text { and } 2 \mathrm{~cm}^{2} \text {, right } \\
\text { cheek and upper lip }\end{array}$ & $\begin{array}{l}\text { Extensive haemangioma } \\
\text { involving the right side of } \\
\text { the face and neck }\end{array}$ & 1 & $\times 2$ & Prednisone & $\begin{array}{l}\text { Treated with excellent result (regression); } \\
\text { ulcerated areas healed in } 2 \text { weeks }\end{array}$ \\
\hline & 6 & $1,4 \mathrm{~cm}^{2}$, neck & $\begin{array}{l}\text { Ulcer in skinfold, area } \\
\text { previously untreated by } \\
\text { laser }\end{array}$ & 1 & No & $\begin{array}{l}\text { Mupirocin, } 2 \text { courses } \\
\text { of oral antibiotics }\end{array}$ & $\begin{array}{l}\text { Rapid improvement, but healing prevented by } \\
\text { repetitive movements of the head and neck }\end{array}$ \\
\hline 8 & 4 & $\begin{array}{l}\text { Multiple, left buttock } \\
\text { and perianal }\end{array}$ & $\begin{array}{l}\text { Painful micturition and } \\
\text { defaecation; difficulty } \\
\text { cleaning the nappy area }\end{array}$ & 10 & $\times 1$ & Oral antibiotics & Healed after 2 weeks \\
\hline 9 & 3 & $1,2 \mathrm{~cm}^{2}$, upper lip & $\begin{array}{l}\text { Feeding difficulties; } 12 \\
\text { weeks premature }\end{array}$ & 4 & $\times 1$ & None & Healed after 3 weeks \\
\hline 10 & 2 & $1,3 \mathrm{~cm}^{2}$, vulva & $\begin{array}{l}\text { Neonatal haemangiomatosis } \\
\text { with liver, heart and } \\
\text { pharyngeal lesions }\end{array}$ & 2 & $\times 1$ & Prednisone, interferon & Healed after 1 week \\
\hline 11 & 12 & $\begin{array}{l}\text { Multiple, } 10 \mathrm{~cm}^{2} \\
\text { vulva, perineum, } \\
\text { perianal }\end{array}$ & $\begin{array}{l}\text { Painful micturition and } \\
\text { defaecation; difficulty } \\
\text { cleaning the nappy area }\end{array}$ & 8 & $\times 1$ & Oral antibiotics & Healed after 3 weeks \\
\hline 12 & 3 & $\begin{array}{l}\text { Multiple, vagina and } \\
\text { vulva }\end{array}$ & $\begin{array}{l}\text { Painful micturition; } 5 \text { weeks } \\
\text { premature; cavernous } \\
\text { haemangioma on right } \\
\text { cheek }\end{array}$ & 5 & $\times 1$ & Oral antibiotics & Healed after 2 weeks \\
\hline 13 & 3 & $1,3 \mathrm{~cm}^{2}$, axilla & & & $\times 2$ & IV and oral antibiotics & $\begin{array}{l}\text { Treated area healed after } 2 \text { weeks; recurrence } \\
\text { in untreated area, healed } 4 \text { weeks after } 2 \text { nd } \\
\text { laser session }\end{array}$ \\
\hline
\end{tabular}

involving a skinfold (patients 6,7 ) required over 10 weeks to heal. Lesions on the lips of patients 4 and 5 were relatively small. These healed in four and three weeks respectively. The eroded haemangioma on the dorsum of the wrist and hand (patient 1) was complicated by multiple bleeding sites and healing was slow (10 weeks) despite the use of compression bandaging.

Conservative treatment in patient 6 was complicated by maceration in the skinfold of the neck which subsequently led to a recurrence due to infection, requiring hospitalisation for intravenous antibiotics. The lesion was finally lasered four months after referral with complete healing in four weeks.

The other patients (7-13), who had laser treatment, had ulcerated areas located close to orifices (lips and perineum) or involved a major flexure. These lesions had not responded to local conservative management and were associated with pain, with impaired feeding, micturition, or defaecation. Lesions of the perineum were complicated by infection and made worse by soiling and nappy changes. All lasered lesions healed significantly quicker than ulcers treated conservatively. This result could not be attributed to a major difference in the size of the ulcerations. There were no complications as a result of laser treatment. Lesions on the lips (patients 7,9 ) responded well after only one laser session. Rapid healing reduced the risk of scarring. Lesions over the perineum (patients 8, 10, 11, 12) all healed within four weeks. Noticeably, pain was alleviated as soon as 24 to 48 hours after laser treatment. Ulceration of the vulva of the patient with neo- natal haemangiomatosis (patient 10; fig 1) occurred despite combined treatment with systemic prednisone and recombinant interferon alfa, and healed within one week after laser treatment.

A second treatment was necessary in two patients. Patient 1 had an extensive haemangioma over the scalp and face and was treated early enough to prevent further growth of the haemangioma. The second treatment was followed by signs of regression which, at 7 weeks of age, is a remarkable result. A second laser session was required for patient 2 due to a recurrence of the ulceration in an adjacent and previously untreated area of haemangioma.

\section{Discussion}

The appearance of ulceration in capillary haemangiomas presents a difficult management problem. Superinfection is frequent and may lead to septicaemia. Ulcerated lesions are often painful and need daily cleaning and dressings for weeks or months. Moreover, the outcome is knowingly poor with frequent scarring and possibly marked disfigurement. It is therefore essential to treat ulcerated capillary haemangiomas as quickly and as efficiently as possible.

The availability of the pulsed dye laser now provides a recognised alternative to conservative management. ${ }^{6}$ In our series, it has proved to be reliable, allowing rapid healing in all cases that were refractory to conservative treatment.

Uncomplicated ulcerated haemangiomas can be managed conservatively. After an initial assessment including microbiological studies, 


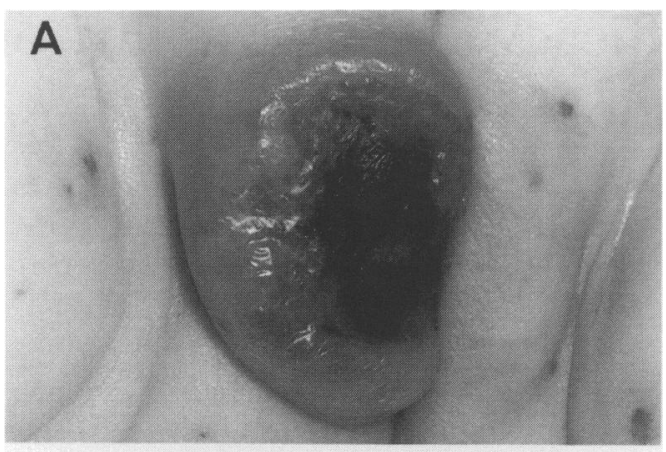

B

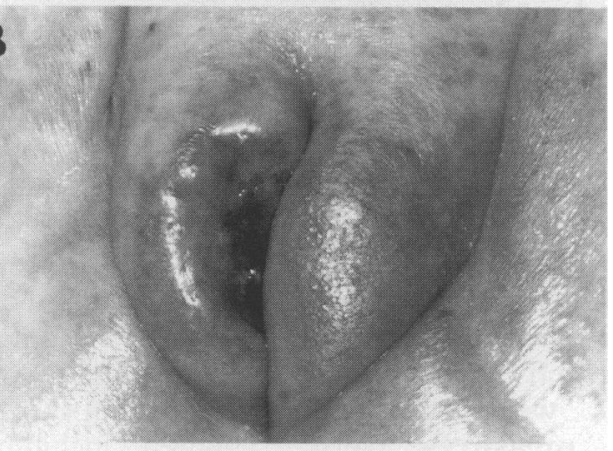

Figure 1 Example of pulsed dye laser treatment for ulcerated capillary haemangiomas. Vulvar ulceration in a baby with neonatal haemangiomatosis (patient 10), before (A) and after (B) laser treatment (48 pulses with a $7 \mathrm{~mm}$ probe at 8 foules/ $\mathrm{cm}^{2}$; re-epithelisation after one week).

careful cleaning with potassium permanganate or chlorhexidine, followed by topical antimicrobial treatment (for example, mupirocin or miconazole) and daily dressings, will allow adequate healing in most cases. Systemic antibiotics are sometimes necessary and compression bandaging may be helpful. ${ }^{8}$

Ulcerated haemangiomas complicated by repetitive trauma and/or maceration, such as those located on the lips, perineum, axilla or on a major skinfold, are often refractory to conservative management and should be considered for pulsed dye laser treatment. As shown in this series, and those of others, ${ }^{67}$ the rapid alleviation of pain is striking. Indeed, pain is often underestimated in infants and most referred cases were not prescribed any analgesia. Another considerable benefit achieved by rapid healing after laser treatment, depending upon the site of the haemangioma, is the restoration of feeding, micturition, or defaecation.

Practical issues enlightened by this review showed that the whole haemangioma and not only the ulcerated area should be treated in order to avoid a recurrence (patients 7 and 13). Laser treatment should be considered early in the management of ulcerated haemangiomas. Indeed, conservative treatment often took over two to three months to achieve healing whereas lasered lesions all healed within a month. It is our experience that such lesions are best treated under general anaesthesia with the support of a paediatric anaesthetic team.

In summary, the approach to the management of ulcerated capillary haemangiomas is outlined in fig 2 . Lesions at risk (on the perineum, lip, or major skinfold) should be identified and referred early to a unit with
Initial assessment

1. History and clinical examination

2. Swabs for bacteria and yeasts

3. Antiseptic soaks $\left(\mathrm{KMnO}_{4}\right.$ or chlorhexidine)

4. Topical antimicrobial agent

5. Daily protective dressings

6. Systemic antibiotics if indicated

mprovement after 1 week

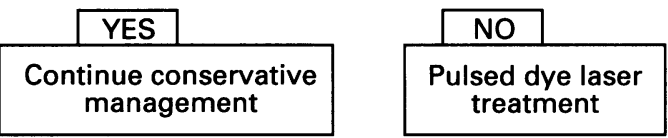

Figure 2 Current guidelines for the treatment of ulcerated capillary haemangiomas. ( $\mathrm{KMnO}_{4}=$ potassium permanganate.)

appropriate laser facilities. If no improvement is seen after one week of optimal conservative treatment, laser treatment should be considered. It is our belief that this approach, by avoiding unwanted delay, reduces the risk of complications, favours rapid healing, and minimises any risk of scarring.

What then is the current role of laser treatment in the management of capillary haemangiomas? It can be regarded as having three major indications. Firstly, it has been proposed that early laser treatment of newly arising capillary haemangiomas, at the age of 3 to 6 weeks, would prevent further growth. ${ }^{9}$ Indeed, the haemangioma of patient 7 in this series showed signs of regression after two laser sessions and we have seen small capillary haemangiomas regress after only one treatment in a premature baby (unpublished observation by the authors). Secondly, as shown in this paper, laser treatment is valuable in the management of ulcerated lesions. Thirdly, laser treatment is the treatment of choice for residual telangiectases after the haemangioma has spontaneously resolved.

Dr M Lacour was supported by a grant from ' $\mathrm{La}$ Fondation Eugenio Litta', Vaduz, Liechtenstein

1 Atherton D. Vascular naevi. In: Champion R, Burton J, Ebling F, ed. Rook, Wilkinson, Ebling, textbook of dermatol ogy. Oxford: Blackwell Scientific Publications, 1993: 469-82.

2 Glassberg E, Lask G, Rabinovitz L, Tunnessen W. Capillary hemangiomas: case study of a novel laser treatment and a review of therapeutic options. F Dermatol Surg Oncol 1989; 15: $1214-23$.

3 Reyes B, Geronemus R. Treatment of port-wine stains during childhood with the flashlamp-pumped pulsed dye laser. $₹$ Am Acad Dermatol 1990; 23: 1142-8.

4 Ashinoff R, Geronemus R. Capillary hemangiomas and treatment with the flash lamp-pumped pulsed dye laser. Arch Dermatol 1991; 127: 202-5.

5 Levine V, Geronemus R. Adverse effects associated with the 577- and 585-nanometer pulsed dye laser in the treatment of cutaneous vascular lesions: a study of 500 patients. $\mathcal{F} \mathrm{Am}$ Acad Dermatol 1995; 32: 613-7.

6 Morelli J, Tan O, Weston W. Treatment of ulcerated hemangiomas with the pulsed tunable dye laser. $A m \mathcal{F}$ Dis Child 1991; 145: 1062-4.

7 Morelli J, Tan O, Yohn J. Treatment of ulcerated hemangiomas in infancy. Arch Pediatr Adolesc Med 1994; 148: 1104-5.

8 Kaplan M, Paller A. Clinical pearl: use of self-adhesive, compressive wraps in the treatment of limb hemangiomas. f Am Acad Dermatol 1995; 32: 117-8.

9 Garden J, Bakus A, Paller A. Treatment of cutaneous hemangiomas by the flashlamp-pumped pulsed dye laser: prospective analysis. 7 Pediatr 1992; 120: 555-60. 